\title{
Curbing the exposure of crooked dealings
}

The only people who think press freedom is a problem are 'crooked politicians' trying to cover up their crooked dealings. Politicians who cannot stand press scrutiny should stay out of public life.

\section{By JOHN GAWI}

THE FREEDOM of the press inquiry referred to the Constitutional Review Commission is an attempt by politicians to curb the exposure of crooked dealings like the recent batch of highly improper and questionable dealings by members of the present Papua New Guinea Government. As far as we ordinary people are concerned, we don't view 'press freedom' as a problem. Rather, our problem right now is crooked politicians.

If politicians are worried about defamation of your 'character' then we ask you: What character are we talking about - theideal personality that you would like to project to the public but cannot live up to, or are we talking about your active personality characterised by greed, lust and aggression?

All that the press can do is portray politicians 'as you are' and not 'as you would like to be'. Therefore, before you start barking up the wrong tree, you ought to delve into the depths of your personality in search of your 'monster' which in this case is not the free press. Your problem is basically an ego problem. If you're looking for a propaganda machine to revamp your ego, then why not set up your own state-owned media organisation? You politicians ought to realise what happens the moment you leave the peace and quiet of your private surroundings for the glamour and litter of public life and enter the political arena to seize those public offices in order to exercise the power, enjoy the privilege, savour the limelight, and have unlimited access to the public purse. Under those circumstances you are deemed to have consented to certain obligations or burdens of office associated with your enjoyment of those public benefits. 
In such a case, the boundary between what is personal life and what is public life does not exist. If it does the it is only in your imagination. You are a public figure accountable to the public at large and 'press scrutiny and press exposure' is simply a minor aspect of such accountability. In any event, your own personal record ought to be impeccable, otherwise you are not a fit and proper person to hold such high public office.

The only people who think press freedom is a problem are crooked politicians trying to cover up their crooked dealings. Entering politics is like a rugby player entering the rugby field; of course, there will be high tackles and an occasional punch - and may be even a broken collarbone; but is that not part and parcel of the game? Politics, like rugby, is not a game for sissies, wee-wees or cry babies. Those of you who cannot stand press scrutiny and press exposure should stay out of public life; or better still, keep your hands off the public till.

If you're serious in saying that you will not tamper with press freedom, but while still upholding it, you are merely trying to make the press more accountable, then let me ask you: What is wrong with our present law on defamation? If you consider that our laws on slander and libel are inadequate, then you tell us first why and how they are so inadequate?

Assuming that our present laws on defamation are inadequate, then the issue is really not one of constitutional reform; the issue becomes that of codification and revamping of the ordinary common law on defamation. We do not want politicians tampering with our constitution and the freedom of our press. Leave press freedom alone. Leave our constitution alone.

We the members of the public are very suspicious about this little constitutional review exercise. Why is it that among the present seven terms of reference, the only substantive one is that of press freedom and accountability. It seems more probable than not that this is a sinister political move to erode press freedom. However, just to pull wool over our eyes, these politicians have simply bundled a few more meaningless exercises like changing the name of our country to 'Open Sesame', or trying to make us sing 'Oh-oh-gung-ho' for our national anthem; or getting rid of the Queen and turning the country into a 'betelnut republic'; or trying to pretend that there is any honour among thieves by talking about 'integrity' of political parties.

This is simply political bluffing so that while we are busy talking about this batch of hotchpotch they are scheming to erode our press freedom. Papua New Guineans must now wake up and tell these politicians to remove this item on press freedom from the present termis of reference.

$\square$ John Gawi is a Papua New Guinean lawyer. He made these comments from the floor during the Constitutional Review Commission seminar on the Governor-General's terms of reference in Port Moresby, 12-14 January 1996. 